\title{
DIRECT SEEDED RICE CULTIVATION METHOD: A NEW TECHNOLOGY FOR CLIMATE CHANGE AND FOOD SECURITY
}

\begin{abstract}
Rice (Oryza sativa) is the major food crop in terms of production and economy and grown in all ecological regions of Nepal. Rice is cultivated traditionally through transplanting of 20-25 days old seedling in the country. Due to unavailability of suitable technology for rice cultivation, there is a huge yield gap in rice production of Nepal. Country has made target of self-sufficiency in rice production by 2020 AD. This target can be achieved through adoption of Direct seeded rice cultivation technology of rice cultivation which also helps to adapt in the climate change scenario of Nepal. Due to issues of water scarcity and expensive labour, direct seeded rice cultivation technology is adopting worldwide. Direct seeded rice is a resource conservation technology and reduces water and labor use by 50\%. Productivity of DSR is $5-10 \%$ more than the yield of transplanted rice. It offers a very exhilarating opportunity to improve water and environmental sustainability. Methane gas emissions is lower in DSR than with conventionally tilled transplanted puddle rice. It involves sowing pre-germinated seeds into a puddled soil surface (wet seeding), standing water (water seeding) or dry seeding into a prepared seedbed (dry seeding). Precise water management, particularly during crop emergence phase (first 7-15 days after sowing), is crucial in direct seeded rice. Furthermore, weed infestation is the major problem, which can cause large yield losses in direct seeded rice. Weed management in DSR can be done through chemical, hand weeding or stale seed bed method.
\end{abstract}

S Marasini ${ }^{1}, \mathrm{TN}$ Joshi, ${ }^{2}$ L P Amgain ${ }^{3}$

Key words: Direct seeded rice, Green house gases, resource conservation, seed priming, weeds management

\section{INTRODUCTION}

Rice stands as the first crop in the Nepalese agriculture and its economy as it is grown in about 1.48 million ha producing 5.47 million tons of rough rice with an average productivity of 3.39 ton/ha (MOAD, 2015). Rice contributes $21 \%$ to the agriculture gross domestic product (GDP) and fulfills $50 \%$ of the calorie requirement of Nepalese people (MOAD, 2015). It is grown in all ecological regions and occupies $71 \%$ area in Terai where as hills and mountain occupies only about 25 and $4 \%$, respectively (NARC, 2012). Of this about 7\% is under double rice crop and $9 \%$ grown as broadcast sown rice (MOAC, 2003).

Productivity of rice is found highest in Egypt ( $8.56 \mathrm{t} / \mathrm{ha})$ followed by Australia $(8.2 \mathrm{t} / \mathrm{ha})$ and South Korea $(6.76 \mathrm{t} / \mathrm{ha})$ which is almost three times greater than that of Nepal (FAO, 1997). The reasons for lower productivity of rice in Nepal may be due to unavailability of quality seed, inadequate weed management practices, little use of improved cultivation practices, lack of fertilizers, lack of irrigation facility, inappropriate government policy etc. There is a potentiality of getting higher productivity of rice in country through generating improved technology. This is essential because the country's target is to achieve over 5 million tones by the year 2020 to be self-sufficient in rice production (Joshi, 1997).

In Nepal, rice is cultivated in traditional way where 20-25 days old seedlings are transplanted in main field. This method of rice cultivation has deleterious effects on the soil environment and for the succeeding wheat and other upland crops and atmospheric environment through emission of

\footnotetext{
${ }^{1}$ Department of Agronomy, Institute of Agriculture and Animal Sciences (IAAS), Kirtipur, Kathmandu

${ }^{2}$ Central Horticultural Farm, Kirtipur, Kathmandu

${ }^{3}$ IAAS Lamjung Campus, Sundar Bazar, Lamjung, Corresponding author: srijana96@gmail.com
} 
methane gas (Dhakal et al., 2012). Therefore, it is suggested that alternate method of planting such as Direct-seeding should be adopted instead of the conventional transplanting to reduce the water and labor demand, which would ultimately decrease the cost of production (Mann et al., 2007). Based on the existing evidence, the present paper reviews the integrated package of technologies for DSR, potential advantages and problems associated with Direct Seeded Rice (DSR), and suggest likely future patterns of changes in rice cultivation.

\section{METHODOLOGY}

Systematic reviews of different published and unpublished papers, journal and books were done and their conclusions were drawn and summarized the evidence by use of explicit methodology. The results of the different articles were summarized in this manuscript.

\section{RESULTS AND DISCUSSION}

\section{DIRECT SEEDED RICE (DSR)}

Direct seeding refers to either wet or dry methods, depending on the manner of crop establishment. Wet-seeding involves sowing pre-germinated seed, either broadcast or drilled, on to puddled wet soil, and then gradually flooding the land. In dry-seeding, rice is broadcast or drilled into dry soil and the seed is then covered. There is also less land preparation. But, good weed control is essential (Suwankadniyom, 2004). In order to save water and labor and promote conservation agriculture (CA), with no/reduced tillage, it is absolutely essential to replace puddle transplanting with direct seeding. In South Asia, DSR is being practiced on terraced and sloppy lands of Bangladesh, along the coast and Western Himalayan region of India (Gupta et al., 2007). It is reported that productivity of DSR is $5-10 \%$ more than the yield of transplanted rice (Sun, 1990).

Table 1. Classification of direct-seeded rice (DSR) system

\begin{tabular}{|c|c|c|c|}
\hline $\begin{array}{l}\text { System of direct } \\
\text { seeding }\end{array}$ & $\begin{array}{c}\text { Seed bed condition and } \\
\text { environment }\end{array}$ & $\begin{array}{c}\text { Sowing method } \\
\text { practiced }\end{array}$ & Suitable ecology/environment \\
\hline $\begin{array}{l}\text { Direct seeding in } \\
\text { dry bed }\end{array}$ & $\begin{array}{l}\text { Dry seeds are sown in dry } \\
\text { and mostly aerobic soil }\end{array}$ & $\begin{array}{l}\text { Broadcasting, Drilling or } \\
\text { sowing in rows at depth } \\
\text { of } 2-3 \mathrm{~cm}\end{array}$ & $\begin{array}{l}\text { Mainly in rain fed area, some in } \\
\text { irrigated areas with precise } \\
\text { water control }\end{array}$ \\
\hline $\begin{array}{l}\text { Direct seeding in } \\
\text { wet bed }\end{array}$ & $\begin{array}{l}\text { Pre germinated seeds sown } \\
\text { in puddled soil, may be } \\
\text { aerobic or anaerobic }\end{array}$ & Various & $\begin{array}{l}\text { Mostly in favorable rainfed } \\
\text { lowlands and irrigated areas } \\
\text { with good drainage facility }\end{array}$ \\
\hline $\begin{array}{l}\text { Direct seeding in } \\
\text { Standing Water }\end{array}$ & $\begin{array}{l}\text { Dry or Pre germinated } \\
\text { seeds sown mostly in } \\
\text { anaerobic condition in } \\
\text { standing water }\end{array}$ & $\begin{array}{c}\text { Broadcasting on } \\
\text { standing water of 5-10 } \\
\mathrm{cm}\end{array}$ & $\begin{array}{c}\text { In areas with red rice or weedy } \\
\text { rice problem and in irrigated } \\
\text { lowland areas with good land } \\
\text { leveling }\end{array}$ \\
\hline
\end{tabular}


Table 2. Comparison of grain yield $\left(\mathrm{t} \mathrm{ha}^{-1}\right)$ in direct seeded and transplanted rice under different ecosystems

\begin{tabular}{|c|c|c|c|c|}
\hline Direct seeded rice & Transplanted rice & Rice ecology & Country & Reference \\
\hline 5.50 & 5.40 & $\begin{array}{l}\text { Shallow wetland- } \\
\text { irrigated }\end{array}$ & Japan & (Harada et al., 2007) \\
\hline 3.83 & 3.63 & Rainfed lowlands & $\begin{array}{l}\text { Thailand and } \\
\text { Combodia }\end{array}$ & (Mitchell et al., 2004) \\
\hline 2.93 & 3.95 & Irrigated & Pakistan & $\begin{array}{l}\text { (Farooq et al., 2006a; } \\
\text { Farooq et al., 2009c) }\end{array}$ \\
\hline 5.40 & 5.30 & Favourable irrigated & India and Nepal & (Hobbs et al., 2002) \\
\hline 5.59 & 5.22 & Favourable irrigated & India & (Sharma et al., 2004) \\
\hline 5.38 & 5.32 & Irrigated & South Korea & (Ko and Kang 2000) \\
\hline 3.15 & 2.99 & $\begin{array}{c}\text { Unfavourable rainfed } \\
\text { lowland }\end{array}$ & India & (Sarkar et al., 2003) \\
\hline 4.64 & 4.17 & Rainfall lowland-hill & India & (Rath et al., 2000) \\
\hline 6.09 & 6.35 & Rainfall lowland-hill & India & (Tripathi et al., 2005a) \\
\hline 2.56 & 3.34 & Irrigated & Pakistan & $\begin{array}{l}\text { (Farooq et al., 2006b; } \\
\text { Faroog et al, 2007) }\end{array}$ \\
\hline 6.6 & 6.8 & Rainfall lowland-hill & India & (Singh et al., 2009a) \\
\hline
\end{tabular}

\section{DIRECT SEEDING: PRESENT STATUS}

In recent years, several countries of Southeast countries of Asia have been shifted from Transplanted Puddled Rice (TPR) to Direct Seeded Rice (DSR) cultivation (Pandey and Velasco, 2002). The shift in TPR to DSR is due to issues of water scarcity and expensive labour (Chan and Nor, 1993). DSR has several benefits to farmers and the environment over conventional practices of puddling and transplanting. Direct seeding helps reduce water consumption by about $30 \%(0.9$ million liters acre1 ) as it eliminates raising of seedlings in a nursery, puddling, transplanting under puddled soil and maintaining 4-5 inches of water at the base of the transplanted seedlings. Direct seeding (both wet and dry), on the other hand, avoids nursery raising, seedling uprooting, puddling and transplanting, and thus reduces the labor requirement (Pepsico International, 2011). Due to avoidance of transplant injury, DSR is established earlier than TPR without growth delays and hastens physiological maturity and reduces vulnerability to late-season drought (Tuong, 2008). The yield levels of DSR are comparable to the Conservation Tillage-TPR in many studies. Some reports claim similar or even higher yields of DSR with good management practices (Table 2). For instance, substantially higher grain yield was recorded in DSR (3.15 t ha-1) than TPR (2.99 t ha-1), which was attributed to the increased panicle number, higher 1000 kernel weight and lower sterility percentage (Sarkar et al., 2003). In addition to higher economic returns, DSR crops are faster and easier to plant, having shorter duration, less labor intensive, consume less water (Bhushan et al., 2007), conducive to mechanization (Khade et al., 1993), have less methane emissions (Wassmann et al., 2004) and hence offer an opportunity for farmers to earn from carbon credits than TPR system (Balasubramanian and Hill, 2002; Pandey and Velasco, 1999).

\section{EMISSION OF GREENHOUSE GASES (GHGS) UNDER DIFFERENT CROP ESTABLISHMENT PRACTICES}

Flooded rice culture with puddling and transplanting is considered one of the major sources of methane $\left(\mathrm{CH}_{4}\right)$ emissions and accounts for $10-20 \%$ (50-100 Tg year-1) of total global annual $\mathrm{CH} 4$ emissions (Reiner and Aulakh, 2000). Amount of $\mathrm{CH} 4$ emission varies between different crop establishment techniques (Aulakh et al., 2001). Most reports claim lower emission of methane gas under DSR compared to other traditional practices (Table 3). Studies comparing $\mathrm{CH} 4$ emissions from different tillage and crop establishment methods (CEM) under similar water management (continuous flooding/mid-season drainage/intermittent irrigation) in rice revealed that $\mathrm{CH} 4$ emissions were lower in DSR than with CT-TPR (Gupta et al., 2002). Methane gas emission and global warming potential was maximum under conventional-TPR and emission of $\mathrm{N}_{2} \mathrm{O}$ was maximum under DSR crop with conservation practice of brown manuring as the addition of organic matter to soil increased the decomposition rate, which resulted in higher emission of GHGs (Bhatia et al., 2011). 


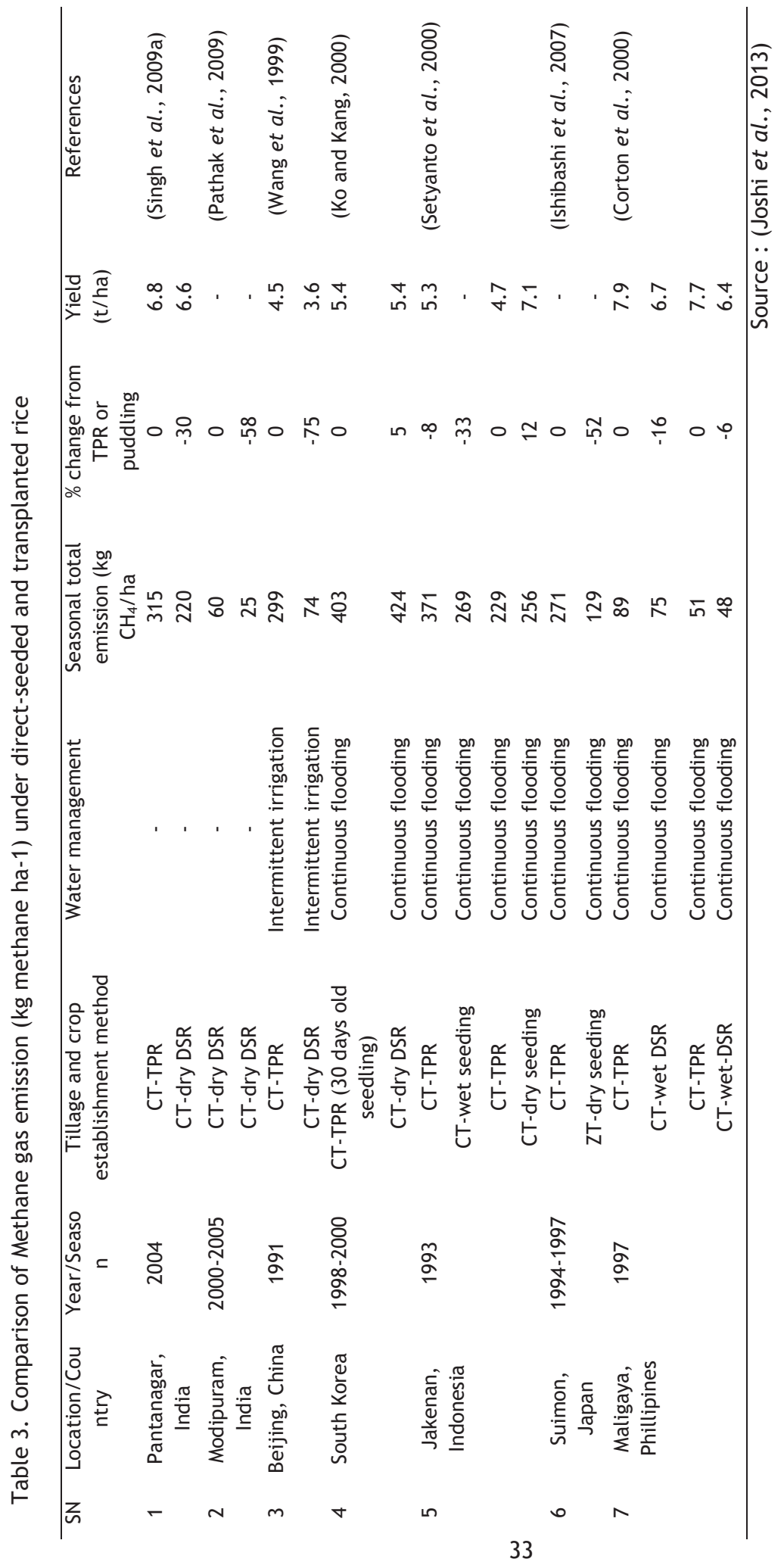




\section{CULTIVAR SELECTION}

Direct dry seeded rice requires specially bred cultivars having good mechanical strength in the coleoptiles to facilitate early emergence of the seedlings under crust conditions (generally formed after light rains), early seedling vigor for weed competitiveness (Zhao et al., 2006), efficient root system for anchorage and to tap soil moisture from lower layers in peak evaporative demands (Pantuwan et al., 2002) and yield stability over planting times are desirable traits for DSR. Varieties suitable for DSR under Neplease context are;

\begin{tabular}{lll}
\hline SN & Geographical Region & Suitable varieties \\
\hline 1 & Terai & Chaite-2, Ghaiya-2, Radha-4, Bindeshwori, Sukha Dhan-1, Sukha-2 and \\
& & Sukha-3, Tarahara-1, Hardinath-2, Sona Masuli \\
2 & Hill & Khumal-4, Khumal-8 and Khumal-10 \\
3 & High Hill & Chhomrong \\
\hline
\end{tabular}

Source : (Shah and Bhurer, 2005)

\section{SEED PRIMING}

One of the short term and the most pragmatic approaches to overcome the drought stress effects is seed priming (Farooq et al., 2006). Seed priming tools have the potential to improve emergence and stand establishment under a wide range of field conditions (Phill 1995). These techniques can also enhance rice performance in DSR culture (Farooq et al., 2006). It involves partial hydration to a point where germination-related metabolic processes begin but radical emergence does not occur (Farooq et al., 2006a). Primed seeds usually exhibit increased germination rate, uniform and faster seedlings growth, greater germination uniformity, greater growth, dry matter accumulation, yield, harvest index and sometimes greater total germination percentage (Farooq et al., 2006b; Kaya et al., 2006).

For primed seed, treatment with fungicide or insecticide should be done post-soaking to control seed borne diseases/insects. Seed can also be soaked in solution having fungicide and antibiotics (Emisan and Streptomycin) for 15-20 hours (Gopal et al., 2010; Gupta et al., 2006). Priming with imidacloprid resulted in increased plant height, root weight, dry matter production, root length, increased yield by $2.1 \mathrm{t}$ ha-1 compared to control (non-primed), which was attributed to higher panicle numbers and more filled grains per panicle (Farooq et al., 2011). Use of biofertilizer like Azospirillum treatment had the highest shoot:root ratio during early vegetative growth and the maximum tillers (Farooq et al., 2011). Seed priming also reduced the need for high seeding rates (Farooq et al., 2011).

\section{EFFECTIVE AND EFFICIENT MANAGEMENT OF WEEDS: A MAJOR CONSTRAINT}

One of the major factors contributing to high yield of DSR is the weed management. Yield of rice is directly affected by weed. Weed reduces the economic yield $(31.5 \%)$ by competing with crop plant for nutrients, moisture, space, light (Gupta, 1987). Weeds are mostly removed from the field manually in traditional method of rice cultivation. But high weed infestation is a major problem in direct-seeded rice (DSR) and causes grain yield losses up to 90 percent (Ghosh, 2002).

Gandhe (Ageratum conyzoides), Lunde (Amaranthus species), Kane (Commelina diffusa), Bhringraj (Eclipta prostrate), Jwane (Fimbristylis miliace) Dubo (Cynodon dactylon), Banso (Digitaria adcendens), Sawa (Echinochloa colona) Kade sawa (Echinochloa crusgalli), Madilo (Ischaemum 
rugosum), Godhe dubo (Paspalum distichum), and Sedges (Cyperus iria, Cyperus difformis) are the major weeds of direct seeded rice (Gaire et al., 2013).

For high productivity of a direct-seeded crop, good and effective weed management is essential. Weed can be managed through Integrated weed management practices which includes stale seed bed techniques in which weeds are allowed to germinate by giving irrigation and then killed by nonselective herbicides two days before seeding, using mulch and subsequently killed by 2,4-D at 30 DAS, and growing of rice varieties having greater ability to compete with weeds. However, 40-50 percent reduced weed densities are reported by mulching. Various mechanical methods are also available for weed control in direct- seeded rice such as manual weeding and using hand weeder. For chemical weed control, it is necessary to select the right herbicide depending upon the weed flora, and the herbicide should be applied with proper spray techniques. Glyphosate (systemic herbicide) or paraquat (contact herbicide) can be used as pre-plant herbicide. pendimethalin, pretilachlor, butachlor, thiobencarb, oxadiazon, oxyfluorfen, and nitrofen are used as preemergence herbicides, almix and fenoxaprop are the most effective post- emergence herbicide used to control the weeds of direct seeded rice. When the stale-bed technique is used to establish a direct dry-seeded rice crop, pre-plant application of glyphosate followed by the pre-emergence herbicide pendimethalin and post-emergence herbicide azimsulfuron/almix can eliminate weed problems in a DSR crop, including weedy rice (Dhakal et al., 2012). However, the best result of weed control can only be seen in case of integrated weed management (Singh et al., 2005).

\section{PRECISE WATER MANAGEMENT}

Precise water management, particularly during crop emergence phase (first 7-15 days after sowing), is crucial in direct seeded rice (Balasubramanian and Hill, 2002). From sowing to emergence, the soil should be kept moist but not saturated to avoid seed rotting. After sowing in dry soil, applying a flush irrigation to wet the soil if it is unlikely to rain followed by saturating the field at the threeleaf stage is essential (Bouman et al., 2007).

There are few reports evaluating mulching for rice, apart from those from China, where 20-90\% input water savings and weed suppression occurred with plastic and straw mulches in combination with DSR compared with continuously flooded TPR (Lin et al., 2003). Bund management also plays an important role in maintaining uniform water depth and limiting water losses via seepage and leakage (Humphreys et al., 2010). Some researchers (Gupta et al., 2006) have recommended avoiding water stress and keeping the soil wet at the following stages: tillering, panicle initiation, and grain filling. Water stress at the time of anthesis results in maximum panicle sterility.

Table 4. Water management schedule in DSR at different phenological stages

\begin{tabular}{lll}
\hline SN & Phenological stages & Irrigation (times) \\
\hline 1 & Pre-sowing & 1 times \\
2 & Emergence of seedling (7-10 days) & 1 times \\
3 & Tillering (30-45 DAS) & 1 times \\
4 & Panicle initiation to grain filling & 1 times \\
\hline
\end{tabular}

Source : (Joshi et al., 2013)

Research showed that 33-53\% irrigation water can be saved in Dry-DSR with AWD as compared with conventional tilled-transplanted puddled rice (CT-TPR) without compromising grain yield (Joshi et al., 2013). 


\section{PEST AND DISEASE MANAGEMENT}

In general, direct seeded rice is affected by similar pests and diseases as transplanted rice; however, under some conditions there may be greater chance of outbreak of insect-pests and diseases in DSR with high rice plant densities. In wet-seeded rice, rats are big problems to crop establishment and it is susceptible to various diseases, rice blast being one of the devastating diseases, in both aerobic and direct-seeded cultures (Bonman and Leung, 2004).

Water deficit and shift from transplanting to direct seeding favors neck blast spread (Kim, 1987). Sometimes the attack of arthropod insect pests is reduced in DSR compared with TPR (Oyediran and Heinrichs, 2001), but a higher frequency of sheath blight and dirty panicle have been observed in DSR (Pongprasert, 1995). For poor Asian farmers use of natural plant derived biocides, such as, those from neem (Azadirachta indica) as it is cheaper, indigenously available and eco-friendly product. Also pathogens cannot easily develop resistance against neem products because they have more than one molecule responsible for biocidal activity. Neem products have been reported to have fungicidal, insecticidal and nematicidal, and antiviral properties (Prasad, 2007). Cultivation of resistant crop varieties and summer ploughing is the pre requisite for efficient management of viral and other diseases/pests. Optimum rate of nitrogenous fertilizers avoid the incidence of brown plant hopper and blast attack. Fumigating the rat burrows with cow dung cake keeping the cow dung balls soaked in kerosene all over the field results in better control of rats and other borrowing animals.

\section{CONCLUSION}

DSR with suitable conservation practices has potential to produce slightly lower or comparable yields as that of TPR and appears to be a viable alternative to overcome the problem of labor and water shortage. Despite controversies, if properly managed, comparable yield may be obtained from DSR compared with TPR. If not managed efficiently, weeds may cause partial to complete failure of DSR crops. On the research front much needs to be done on the nutrient dynamics in soils under DSR. Also, research is needed on soil ecology in rice soils and weed management in DSR. Under different rice production zones need to develop a site-specific package of production technologies for different rice production systems. Varieties capable of synthesizing osmoprotectants and capable of synthesizing stress proteins may be introduced. Although methane emissions are substantially reduced in DSR, but, to combat increase in $\mathrm{N}_{2} \mathrm{O}$ emission here is need to monitor GHG's emissions and develop strategies to reduce $\mathrm{N}$ losses vis-a-vis $\mathrm{N}_{2} \mathrm{O}$ emissions under aerobic conditions for safer environment. Effective management strategies for pest and disease dynamics will help to resolve the issues of blast and insect infestation in DSR. Optimization of crop residue cover needs in systems' perspective.

\section{ACKNOWLEDGEMENTS}

Authors are thankful to Mr. Madhav Dhakal, Agriculture Officer, NARDF, Kathmandu for providing reference materials for the manuscript.

\section{REFERENCES}

Balasubramanian, V. and Hill, J.E, 2002. Direct seeding of rice in Asia: emerging issues and strategic research needs for the 21st century. In: Pandey, S., Mortimer, M., Wade, L., Tuong, T.P, Lopez, K. and 
Hardy, B. (eds.) Direct Seeding: Research Strategies and Opportunities. International Rice Research Institute, Los Banos, Philippines, pp 15-42.

Bhatia, A., Ghosh, A., Kumar, V., Tomer, R., Singh, S.D and Pathak, H., 2011. Effect of elevated tropospheric ozone on methane and nitrous oxide emission from rice soil in north India. Agric Ecosys Environ. 144:21-28.

Bhushan, L., Ladha, J.K., Gupta, R.K., Singh, S., Tirol-Padre, A., Saharawat, Y.S., Gathala, M., Pathak, H., 2007. Saving of water and labor in a rice-wheat system with no-tillage and direct seeding technologies. Agron J. 99: 1288-1296.

Bonman, J.M., Leung, H., 2004. Breeding for durable resistance to rice blast disease dream or reality? Phytopathology 93, S113 Publication No. P-2003-0110-SSA. American Phytopathological Society Annual Meeting.

Bouman, B.A.M., Lampayan, R.M., Tuong, T.P., 2007. Water Management in Irrigated Rice: Coping with Water Scarcity. International Rice Research Institute, Los Banos, Philippines, 54p.

Dhakal, M., Shah, S.K., MC Donald, A. and Basnet, K.B., 2013. Weed management on direct seeded rice (DSR). Unpublished thesis, Tribhuvan University, Institute of Agriculture and Animal Sciences, Rampur, Chitwan, Nepal.

Farooq, M., Basra, S.M.A., Afzal, I., Khaliq, A., 2006. Optimization of hydro-priming techniques for rice seed invigoration. Seed Sci. Technol. 34: 507-512.

Gaire, R., Dahal, K.R., and Amgain, L.P., 2013. Effect of different mulching materials on weed dynamics and yield of direct seeded rice in Chitwan, Nepal, Agronomy Journal of Nepal, 3: 73.

Gao, X.P., Zou, C.Q., Fan, X.Y., Zhang, F.S., Hoffland, E., 2006. From flooded to aerobic conditions in rice cultivation: consequences for zinc uptake. Plant Soil. 280: 41-47.

Gopal, R., Jat, R.K., Malik, R.K., Kumar, V., Alam, M.M., Jat, M.L., Mazid, M.A., Saharawat, Y.S., McDonald, A., Gupta, R., 2010. Direct Dry Seeded Rice Production Technology and Weed Management in Rice Based Systems. Technical Bulletin. International Maize and Wheat Improvement Center, New Delhi, India, 28pp.

Gupta, R.K., Ladha, J.K., Singh, S., Singh, R., Jat, M.L., Saharawat, Y., Singh, V.P., Singh, S.S., Singh, G., Sah, G., Gathala, M., Sharma, R.K., 2006. Production Technology for Direct Seeded Rice. Technical Bulletin Series 8. In "Rice-Wheat Consortium for the Indo-Gangetic Plains, New Delhi, India," 14pp.

Gupta, R.K., Ladha, J.K., Singh, S.R., Singh, M.L., Jat, Y., Saharawat, V.P., Singh, S.S., Singh, G., Singh, G., Sah, Gathala, M., Sharma, R.K., 2007. Production Technology for Direct Seeded Rice. Technical Bulletin Series 8. In "Rice-Wheat Consortium for the Indo-Gangetic Plains, New Delhi, India," 14pp.

Humphreys, E., Kukal, S.S., Christen, E.W., Hira, G.S., Sharma, R.K., 2010. Halting the groundwater decline in north-west India-Which crop technologies will be winners? Adv Agron. 109: 155-217.

Joshi, E., Kumar, D. Lal, B.V., Gautam, P. and Vyas, A.K., 2013. Management of direct seeded rice for enhanced resource - use efficiency. Plant Knowledge Journal 2(3): 119-134.

Kaya, M.D., Okcub, G., Ataka, M.C., Ikilic, Y., Kolsarica, O., 2006. Seed treatments to overcome salt and drought stress during germination in sunflower (Helianthus annuus L.). Eur J Agron. 24: 291-295.

Khade, V.N., Patil, B.D., Khanvilkar, S.A., Chavan, L.S., 1993. Effect of seeding rates and level of $N$ on yield of direct-seeded (Rahu) summer rice in Konkan. J Maharash Agric Univ. 18: 32-35. 
MoAC, 2003. Statistical information on Nepalese agriculture. Agribusiness Promotion and Statistics Division, Singh Darbar, Kathmandu.

MoAD, 2015. Statistical information on Nepalese agriculture. Agribusiness Promotion and Statistics Division, Singh Darbar, Kathmandu.

MOAD, 2015. Area, production and yield of cereal crops in Nepal. Pp. 4. In: Statistical Information on Nepalese Agriculture 1999/00. Agri.Business Promotion and Statistics Division, Ministry of Agriculture and Cooperatives (MoAC), Singh Durbar, Kathmandu, Nepal.

NARC, 2012. Annual Report. National Research Council, Khumaltar. pp. 28.

NARC, 2012. Physical Constraints. In: Status of Rice Research and Production in Nepal. Nepal Agricultural Research Council, Khumaltar, Lalitpur, Nepal.

Oyediran, I.O., Heinrichs, E.A., 2001. Arthropod populations and rice yields in directseeded and transplanted lowland rice in West Africa. Int J Pest Manage. 47: 195-200.

Pandey, S., Velasco, L., 2002. Economics of direct seeding in Asia: patterns of adoption and research priorities. In: Pandey, S., Mortimer, M., Wade, L., Tuong, T.P., Lopes, K., Hardy, B. (eds.). Direct Seeding: Research Strategies and Opportunities. International Rice Research Institute, Los Banos Philippines.

Pantuwan, G., Fukai, S., Cooper, M., Rajatasereekul, S., and Toole, J.C. 2002. Yield response of rice (Oryza sativa L.) genotypes to different types of drought under rainfed lowlands. Plant factors contributing to drought resistance. Field Crops Res. 73: 181-200.

Pepsico International, 2011. Direct seeding of paddy- the work of pepsico reported in indiawaterportal. http://www.indiawaterportal.org/post/6 754.

Pongprasert, S., 1995. Insect and disease control in wet-seeded rice in Thailand. In: Moody, K. (ed.), Constraints, Opportunities, and Innovations for Wet-seeded Rice, Discussion Paper Series No. 10. International Rice Research Institute, Los Bano s, Philippines, pp 118-132.

Prasad, R., 2007. Phosphorus management in the rice-wheat cropping system of the Indo- Gangetic Plain. Better Crops-India. 1: 8-11.

Rao, A.N., Johnson, D.E., Sivaprasad, B., Ladha, J.K., Mortimer, A.M. 2007. Weed management in directseeded rice. Adv Agron. 93: 153-255.

Reiner, W., Aulakh, M.S., 2000. The role of rice plants in regulating mechanisms of methane emissions. Biol Fertil Soils. 31: 20-29.

Sarkar, R.K., Sanjukta, D., Das, S., 2003. Yield of rainfed lowland rice with medium water depth under anaerobic direct seeding and transplanting. Trop Sci. 43: 192-198.

Singh, S., Malik, R.K., Mongia, A.D., Sharma, R.K., Sidhu, B.S., Singh, B., 2005. Haryana \& Punjab. In “Agenda Notes. 13th Regional Technical Co-Ordination Committee Meeting, 6-8 February 2005, Dhaka, Bangladesh," pp 27-29.

Tuong, L., 2008. Studies on direct-seeding adaptability of Cambodian rice cultivars and development of cultivars with good eating quality. PhD thesis, Science of Plant and Animal Production, United Graduate School of Agricultural Science, Tokyo University of Agriculture and Technology, Japan.

Wassmann, R., Neue, H.U., Ladha, J.K., Aulakh, M.S., 2004. Mitigating greenhouse gas emissions from ricewheat cropping systems in Asia. Environ Sustain Dev. 6: 65-90. 